Available online at GSC Online Press Directory

GSC Biological and Pharmaceutical Sciences

e-ISSN: 2581-3250, CODEN (USA): GBPSC2

Journal homepage: https://www.gsconlinepress.com/journals/gscbps

(RESEARCH ARTICLE)

\title{
Changes in semen characteristics and sex hormones of rats treated with iron oxide nanoparticles, silver nanoparticles and their mixture
}

\author{
Ahmed Ibrahim Younus $1{ }^{1}{ }^{*}$, Mokhtar Ibrahim Yousef ${ }^{2}$, Maher Abdel-NabiKamel ${ }^{3}$, Rakhad Alrawi ${ }^{4}$ and \\ Jubran Mohammed Abdulrahman ${ }^{5}$ \\ ${ }^{1}$ Ministry of Health, Iraq. \\ ${ }^{2}$ Department of Environmental Studies, Institute of Graduate Studies and Research, Alexandria University, Egypt. \\ ${ }^{3}$ Department of Biochemistry, Medical Research Institute, Alexandria University, Egypt. \\ ${ }^{4}$ Grand Canyon University and Arizona College. Arizona, USA. \\ ${ }^{5}$ Center of Research and Educational Studies, Ministry of Education, Iraq.
}

Publication history: Received on 21 August 2020; revised on 26 August 2020; accepted on 29 August 2020

Article DOI: https://doi.org/10.30574/gscbps.2020.12.2.0272

\begin{abstract}
Few studies have demonstrated the toxicity of iron oxide nanoparticles ( $\mathrm{Fe}_{2} \mathrm{O}_{3} \mathrm{NPs}$ ), and silver nanoparticles (AgNPs), and their combination on reproductive performance.Therefore, the present study aimed to investigate the reproductive toxicity of iron oxide nanoparticles, silver nanoparticles and their combination in male rats. Forty Wistar male rats were divided into 4 equal groups. Group 1 served as control, group 2 was administered orally with $\mathrm{Fe}_{2} \mathrm{O}_{3} \mathrm{NPs}(5 \mathrm{mg} / \mathrm{kg} \mathrm{BW}$; $<50 \mathrm{~nm}$ ), group 3 was treated intraperitoneally with AgNPs $(50 \mathrm{mg} / \mathrm{kg} \mathrm{BW;}<100 \mathrm{~nm}$ ) and group 4 was administered with the mixture of $\mathrm{Fe}_{2} \mathrm{O}_{3} \mathrm{NPs}$ with AgNPs. Animals were treated with doses every day for 79 days. The results revealed that semen parameters (sperm count, abnormal sperm and sperm motility) of adult male rats treated with $\mathrm{Fe}_{2} \mathrm{O}_{3} \mathrm{NPs}$, AgNPs and their combination showed significant $(\mathrm{P}<0.05)$ reduction in sperm motility and sperm count, and significant $(\mathrm{P}<0.05)$ induction in abnormal sperm compared to the control group. Results also showed significant $(\mathrm{P}<0.05)$ decrease in the levels of testosterone and TSH, and significant $(\mathrm{P}<0.05)$ increase in FSH, LH, T3 and T4 levels in rats treated with $\mathrm{Fe}_{2} \mathrm{O}_{3} \mathrm{NPs}$, AgNPs and their combination compared to the control group. The specific activity of testicular $17 \beta$-hydroxysteroid dehydrogenase (17 $\beta$-HSD) was significantly decreased, while 17-ketosteroid reductase (17-KSR) was significantly increased in animals treated with $\mathrm{Fe}_{2} \mathrm{O}_{3} \mathrm{NPs}$, AgNPs and their combination compared to the control group. It was concluded that rats exposed to $\mathrm{Fe}_{2} \mathrm{O}_{3} \mathrm{NPs}$, AgNPs or their combination caused testes inflammation and sex hormones imbalance that affect reproductive performance.
\end{abstract}

Keywords:Iron oxide nanoparticles; Silver nanoparticles; Male rats; Semen characteristics; Sex hormones.

\section{Introduction}

Iron oxide nanoparticles, subsequently increasing their existing levels in the environment and human exposure, the increased exposure can influence upon society in many ways, such as potential risk to human health, in particular to pregnant women or babies. Therefore, it is critically important to understand the developmental and reproductive toxicity and the long-term effects of iron oxide nanoparticles [1]. Nowadays, an important growing in nanotechnology has lead to the increased production and application of several nanostructure materials, including silver nanoparticles (AgNPs). This kind of nanoparticles has been incorporated into several products such as cosmetics, textiles, and medicines for their bactericidal effect [2, 3]. Because of their antimicrobial, optical, and catalytic properties, silver nanoparticles (SNP) have gained particular interest for many commercial applications. According to the Woodrow Wilson Inventory, approximately $30 \%$ of all nanoparticles-enabled products contain nanosilver. Thus, SNP are highly commercialized and are now being used in many daily

\footnotetext{
${ }^{*}$ Corresponding author: Ahmed Ibrahim Younus

Ministry of Health, Iraq.
}

Copyright $(C 2020$ Author(s) retain the copyright of this article. This article is published under the terms of the Creative Commons Attribution Liscense 4.0. 
life products mainly because of their antimicrobial properties. In clear contrast to SNP widespread use, putative health effects have only just begun of being adequately addressed [4].Very little is known about the toxicity of nano-sized silver particles, however, the size and surface area are recognized as important determinants for toxicity [5]. Significant concerns have been expressed about the potential risk of silver nanoparticles (AgNPs), due to the current and projected high exposure [6]. A few research groups have investigated the toxicity of silver nanocomposites and nanoparticles in cell lines to estimate viability and reactive oxygen species (ROS) generation [7 - 9].Despite the wide application of nanoparticles, there is a serious lack of information concerning their impact on human health and the environment [5]. From the previous literature, there is a shortage in the information on the effects of iron oxide nanoparticles $\left(\mathrm{Fe}_{2} \mathrm{O}_{3} \mathrm{NPs}\right.$ ), silver nanoparticles (AgNPs) or their combination on male fertility and their mechanism of reproductive toxicity.

\section{Aim of the study}

The present study was carried out to investigate the reproductive toxicity of $\mathrm{Fe}_{2} \mathrm{O}_{3} \mathrm{NPs}$ and AgNPs alone or in combination in male rats fertility parameters (semen characteristics, sex hormones, testosterone, luteinizing hormone, follicle-stimulating hormone, thyroid stimulating hormone, thyroxine and triiodothyronine).

\section{Material and methods}

The epididymis was sampled at the end of the experiment. Spermatozoa obtained from the caudaepididymis were subsequently diluted with physiologicalsolution $(20 \mu \mathrm{l})$ at $37^{\circ} \mathrm{C}$. The sample was located in the Makler chamber (SefiMedical Instruments, Germany). Analysis was realized using a CASA System-Supervision (Minitüb, Tiefenbach, Germany) with Olympus BX 51(Olympus, Japan) microscope as described by Krause 10]. The sperm count; motile sperm percentage and abnormal spermmorphology (\%) were evaluated in the experimental groups according to the method of Dunson et al. [11]. A drop of $1 \%$ eosin-Y staining was added to the sperm sample on amicroscope slide at 400x magnification for morphological studies [12].Plasma testosterone rat enzyme-linked immunosorbent assay (ELISA) is a competitive immunoassay for the quantitative measurement of testosterone in rat, was estimated by the method of Zirkin and Chen [13] and Sakuma [14].The ELISA technique uses antibodies with high affinity and specificity for two different epitopes on rat follicle stimulating hormone (FSH) was estimated by the method of Kjeld et al. [15]. Furthermore, the ELISA kit applies to the in vitro quantitative determination of rat luteinizing hormone (LH) concentrations in plasma was estimated by the method of Closset and Hennen [16] and Teerds et al. [17]. Rat thyroid stimulating hormone (TSH) was assayed by using ELISA kit for the quantitative determination of rat TSH concentrations in plasma (CUSABIO BIOTECH CO., LTD.). Triiodothyronine (T3) was assayed by using ELISA Kit for the quantitative measurement of (T3) in rat plasma (Abnova CO., KA 0925). Moreover, (T4) was assayed by using ELISA kit in vitro quantitative detection of rat in plasma (Biovision CO., U.S.A). Streoidgenic 17-ketosteroidreductase enzyme activity (17-KSR; EC 1.1.1.64) was estimated by the method of Katryna and Anita [18]. Specific activity of $17 \beta$-hydroxyl steroid hdrogenase enzyme activity (17 $\beta$-HSD; EC 1.1.1.51) was estimated by the method of Bogovich and Payne [19].Interleukin-6 (IL-6) ELISA Kit for the in vitro quantitative measurement of rat IL-6 in tissue homogenates was estimated by the method of Ferguson-Smith et al. (1988). Tumor Necrosis factor alpha (TNF- $\alpha$ ) rat in vitro ELISA (Enzyme-Linked Immunosorbent Assay) kit is designed for the quantitative measurement of rat TNF- $\alpha$ in cell culture supernatants. It was estimated by the method ofHedayati et al. [20].The tumor suppressor P53 acts primarily as a transcriptional activator that controls the expression of many genes was estimated by the method ofHupp et al. [21], Renard et al. [22], Gottifredi and Prives [23] and Yang et al. [24]. The Trans AM Kit combines a fast and user-friendly ELISA format with a sensitive and specific assay for transcription factors. TransAM p53 Kits contain a 96-well plate on which has been immobilized an oligonucleotide that contains a p53 consensus binding site (5'GGACATGCCCGGGCATGTCC-3'). P53 contained in nuclear extract specifically binds to this oligonucleotide. The primary antibody used in TransAM p53 Kit recognizes an accessible epitope on p53 protein upon DNA binding. Addition of a secondary HRP-conjugated antibody provides a sensitive colorimetric readout easily quantified by spectrophotometry.

\section{Results and discussion}

The changes in semen characteristics (sperm count, sperm motility and abnormal sperm) of adult male rats treated daily for 79 days with iron oxide nanoparticles $\left(\mathrm{Fe}_{2} \mathrm{O}_{3} \mathrm{NPs}\right.$ ), silver nanoparticles (AgNPs) and their combination are summarized in Table 1 and Figures 1. Results showed that $\mathrm{Fe}_{2} \mathrm{O}_{3} \mathrm{NPs}$, AgNPs and their combination caused significant $(\mathrm{P}<0.05)$ reduction in sperm motility and sperm count, and significant $(\mathrm{P}<0.05)$ induction in abnormal sperm compared to the control group. The effects of the combination of $\mathrm{Fe}_{2} \mathrm{O}_{3} \mathrm{NPs}$ and AgNPs were more toxic than each one. Table 2 and Figures 2 and 3 represented data of testosterone, follicle stimulating hormone (FSH), luteinizing hormone (LH), thyroidstimulating hormone (TSH), Thyroxin (T4) and tri-iodothyronine (T3) of adult male rats treated with $\mathrm{Fe}_{2} \mathrm{O}_{3} \mathrm{NPs}$, AgNPs and their combination. Results alsoshowed significant $(\mathrm{P}<0.05)$ decrease in the levels of testosterone and TSH, and 
significant $(\mathrm{P}<0.05)$ increase in $\mathrm{FSH}, \mathrm{LH}, \mathrm{T} 3$ and T4 levels in rats treated with $\mathrm{Fe}_{2} \mathrm{O}_{3} \mathrm{NPs}$, AgNPs and their combination compared to the control group, and these effects were more pronounced in the combination group.

Table 1 Mean values \pm SE of semen characteristics and hormone levels of male rats treated with iron oxide nanoparticles ( $\mathrm{Fe}_{2} \mathrm{O}_{3} \mathrm{NPs}$ ), silver nanoparticles (AgNPs) and their combination.

\begin{tabular}{|l|l|l|l|l|}
\hline \multirow{2}{*}{ Parameter } & \multicolumn{3}{l|}{ Experimental groups } \\
\cline { 2 - 5 } & Control & Fe203NPs & AgNPs & Fe203NPs+ AgNPs \\
\hline Sperm count (10 6/g tissue) & $79 \pm 4.2 \mathrm{a}$ & $37 \pm 1.6 \mathrm{~b}$ & $39 \pm 1.6 \mathrm{~b}$ & $19 \pm 0.9 \mathrm{c}$ \\
\hline Abnormal (\%) & $6 \pm 0.5 \mathrm{~d}$ & $26 \pm 1.6 \mathrm{~b}$ & $21 \pm 1.2 \mathrm{c}$ & $37 \pm 1.8 \mathrm{a}$ \\
\hline Motility(\%) & $78 \pm 4.3 \mathrm{a}$ & $56 \pm 1.8 \mathrm{~b}$ & $47 \pm 1.9 \mathrm{c}$ & $28 \pm 1.8 \mathrm{~d}$ \\
\hline
\end{tabular}

Mean values within a row not sharing a common superscript letters $(a, b, c)$ were significantly different, $p<0.05$.
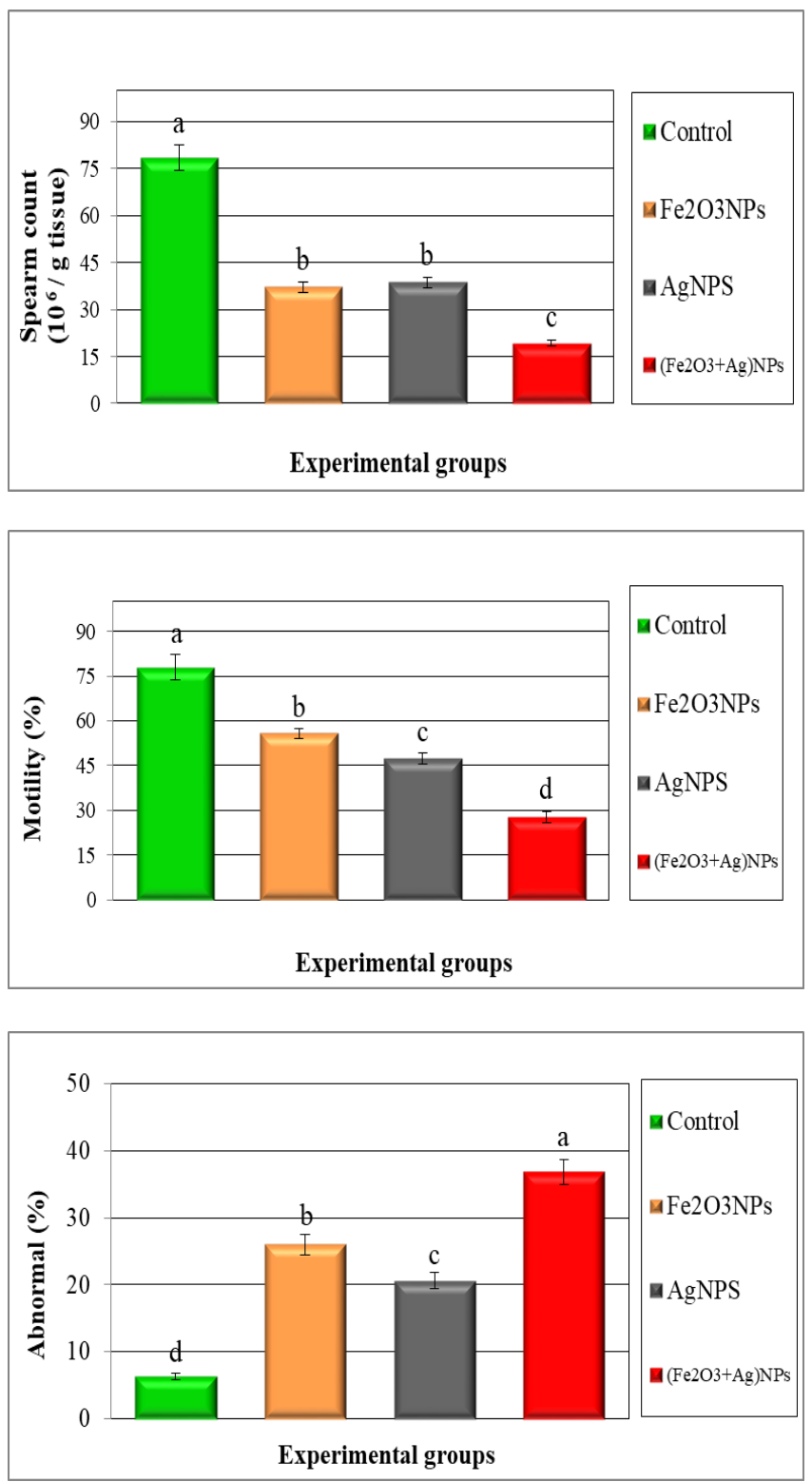

Figure 1Mean values \pm SE of semen characteristics and hormone levels of male rats treated with iron oxide nanoparticles ( $\mathrm{Fe}_{2} \mathrm{O}_{3} \mathrm{NPs}$ ), silver nanoparticles (AgNPs) and their combination 
The reproductive and developmental toxicity of nanomaterials has become increasingly recognized as an important part of the nanotoxicology (1). Yoshida et al. [25] found that nanoparticles produced during the process of diesel engine fuel combustion caused reduction in the fertility. They reported that the reduction is related to Leydig cell degeneration and the damage to the seminiferous tubules. Also, the presence of cytokines disrupts testosterone synthesis process in leydig cells by directly affecting the expression of the genes which are influential on testosterone process and the following inhibition of testosterone synthesis. So, cytokines presence is deemed to be a chronic disruptive factor for cholesterol synthesis [26].Nano-particles can cause inflammation of the epididymis, which has a role in reduction of sperm motility [27]. Carlson et al. [28] reported that three factors combine to render sperm particularly susceptible to free radical damage, a high membrane concentration of polyunsaturated fatty acids, active generation of free radicals and a lack of defensive enzymes. All of these factors combine to make the health of the sperm critically dependent upon antioxidants. Yoshida et al. [29] reported that nanoparticles increase free radicals in the sperm cells. This can damage the sperm membrane and flagellum structure and disrupt sperm motility and morphology. Free radicals lead to peroxidation of phospholipids in the mitochondria of the spermatozoa and thus impair their ultimate motility [30].

It is also demonstrated that reactive oxygen species (ROS) level is positively correlated with the proportion of sperm with amorphous heads, damaged acrosomes, midpiece defects, cytoplasmic droplets and tail defects [31]. Nasri et al. [32] found that $\mathrm{Fe}_{2} \mathrm{O}_{3}$ nanoparticles cause a meaningful reduction in sperm numbers and mobility and cause the inflammation of epididymis and increasing of free radicals. In accordance to these literatures, the present study showed that treatment with $\mathrm{Fe}_{2} \mathrm{O}_{3} \mathrm{NPs}$, AgNPs and their combination caused significant increase in testes thiobarbituric acid reactive substances (TBARS), nitric oxide (NO), and decrease in the activities of antioxidant enzymes (SOD, CAT, GPX and GST), total antioxidant capacity and reduced glutathione in testes and this may be caused deterioration in semen characteristics (Table 1 and Figure 1). The decrease in sperm motility and sperm count is in agreement with Nasri et al. [32] who studied the effects of iron oxide nanoparticle $(5,10,20$ and $40 \mathrm{mg} / \mathrm{kg} \mathrm{BW})$ on sperm numbers and motility in male mice. The investigation of sperm mobility in the epydidimal area shows that the percentage of sperm mobility in the mice in experimental group in relation to control group has had a meaningful decrease, that it can be said the reason is related to the effect of iron oxide nanoparticles on mitochondrial action [7]. The researches which have done on the effect of nanoparticles on mitochondrial action in different cells have shown the reduction of mitochondrial action in all cases. On the line, 4-18 cells showed that nanoparticles such as iron oxide and silver can cross the membrane of sperm and they can connect to mitochondria and acrosome of sperm cases [7]. On the other hand, sperm mobility was happened in epididymis, the investigation shows that nanoparticles can effect on epididymis and cause the inflammation of epididymis that it can reduce sperm mobility. Also nanoparticles in cells cause the increasing of ROS that this can decrease the mobility of the cells by damaging to the flagella structure of the sperms [29]. Metal nanoparticles increase ROS such as super oxide which may cause the inhibit of RNA polymerase [29], the oxidation of molecules such as protein and even DNA and in this way they cause the decrease of LH, testosterone and Leydig cells [33].

Table 2 Mean values \pm SE of testosterone, follicle stimulating hormone, luteinizing hormone, thyroid-Stimulating, hormone, tri-iodothyronine and thyroxin of male rats treated with iron oxide nanoparticles ( $\mathrm{Fe}_{2} \mathrm{O}_{3} \mathrm{NPs}$ ), silver nanoparticles (AgNPs) and their combination.

\begin{tabular}{|l|l|l|l|l|}
\hline \multirow{2}{*}{ Parameter } & \multicolumn{4}{l}{ Experimental groups } \\
\cline { 2 - 5 } & Control & Fe203NPs & AgNPs & Fe203NPs+AgNPs \\
\hline Testosterone $(\mathrm{ng} / \mathrm{ml})$ & $6.1 \pm 0.42 \mathrm{a}$ & $1.8 \pm 0.10 \mathrm{~b}$ & $2.8 \pm 0.18 \mathrm{c}$ & $0.8 \pm 0.05 \mathrm{~d}$ \\
\hline FSH $(\mathrm{ng} / \mathrm{ml})$ & $0.8 \pm 0.05 \mathrm{c}$ & $1.8 \pm 0.12 \mathrm{~b}$ & $1.5 \pm 0.09 \mathrm{~b}$ & $3.0 \pm 0.22 \mathrm{a}$ \\
\hline $\mathrm{LH}(\mathrm{ng} / \mathrm{ml})$ & $0.4 \pm 0.01 \mathrm{c}$ & $0.9 \pm 0.07 \mathrm{~b}$ & $1.1 \pm 0.08 \mathrm{~b}$ & $1.8 \pm 0.06 \mathrm{a}$ \\
\hline TSH $(\mathrm{ng} / \mathrm{ml})$ & $4.7 \pm 0.26 \mathrm{a}$ & $2.8 \pm 0.19 \mathrm{~b}$ & $2.1 \pm 0.11 \mathrm{c}$ & $1.1 \pm 0.08 \mathrm{~d}$ \\
\hline T3 $(\mathrm{ng} / \mathrm{ml})$ & $77 \pm 4.5 \mathrm{c}$ & $157 \pm 6.9 \mathrm{~b}$ & $154 \pm 7.5 \mathrm{~b}$ & $197 \pm 6.1 \mathrm{a}$ \\
\hline T4(ng/ml) & $1.0 \pm 0.06 \mathrm{c}$ & $2.6 \pm 0.18 \mathrm{~b}$ & $1.8 \pm 0.07 \mathrm{~b}$ & $3.9 \pm 0.15 \mathrm{a}$ \\
\hline \multicolumn{2}{|l}{ Mean values within a row not sharing a common superscript letters $(\mathrm{a}, \mathrm{b}, \mathrm{c})$ were significantly different, $\mathrm{p}<0.05}$. \\
\hline
\end{tabular}

FSH $=$ Follicle stimulating hormone, $\mathrm{LH}=$ Luteinizing hormone, $\mathrm{TSH}=$ Thyroid-Stimulating Hormone, $\mathrm{T} 3=$ Tri-Iodothyronine, $\mathrm{T} 4=$ Thyroxin.

The present study showed that treatment with $\mathrm{Fe}_{2} \mathrm{O}_{3} \mathrm{NPs}$, AgNPs and their combination caused significant increase in T4 and T3 (Table 2 and Figure 3). In rats, T3 affects testis maturation, and thyroid receptor (TR) type-1 (TR-1) expression in rats' testes $[34,35]$. Maximal Sertoli cell proliferation coincides with maximal T3 binding capacity in testis, 
suggesting that the main target of T3 action is the Sertoli cell. However, T3 also plays a significant role in differentiation of the seminiferous epithelium, and studies in rodents have shown that T3 is an important factor in maturation of Leydig cells. The presence of T3 is necessary to initiate differentiation of mesenchymal cells into Leydig progenitor cells, and T3 works in concert with other hormones (luteinizing hormone; LH and Insulin-like growth factor 1; IGF-1) to promote Leydig cell development [36].

It was concluded that rats exposed to $\mathrm{Fe}_{2} \mathrm{O}_{3} \mathrm{NPs}$ and AgNPs and their combination caused testes inflammation and sex hormones imbalance that affect semen characteristics.
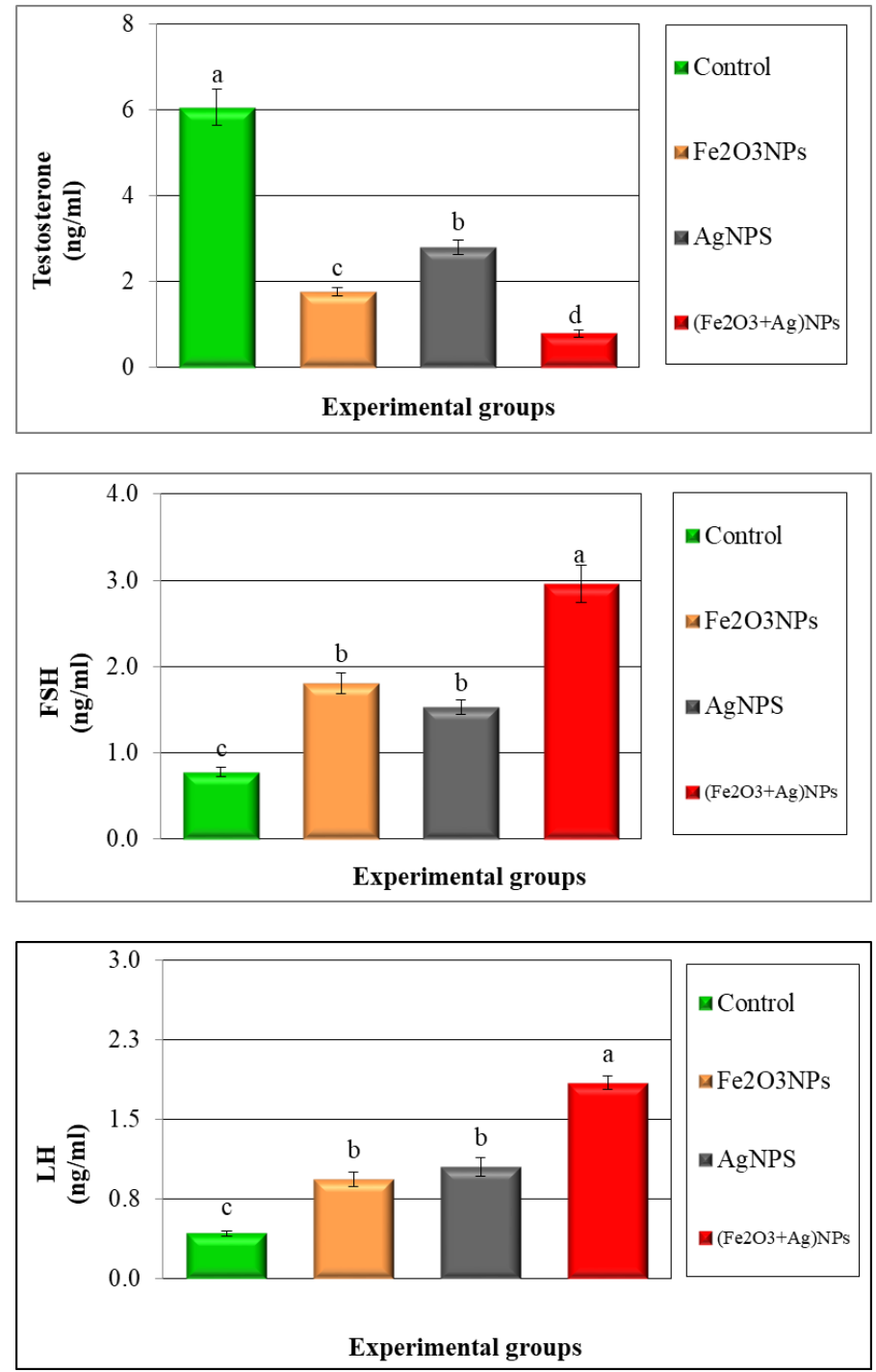

Figure 2 Mean values \pm SE of testosterone, follicle stimulating hormone and luteinizing hormone of male rats treated with iron oxide nanoparticles ( $\mathrm{Fe}_{2} \mathrm{O}_{3} \mathrm{NPs}$ ), silver nanoparticles (AgNPs) and their combination.

Table 3 and Figure 4 showed steroidogenic enzymes (17 $\beta$-hydroxysteroid dehydrogenase; $17 \beta$-HSD and 17-ketosteroid reductase; 17-KSR) of adult male rats treated daily for 79 days with iron oxide nanoparticles ( $\mathrm{Fe}_{2} \mathrm{O}_{3} \mathrm{NPs}$ ), silver nanoparticles (AgNPs) and their combination. Data showed that $\mathrm{Fe}_{2} \mathrm{O}_{3} \mathrm{NPs}$, AgNPs and their combination caused significant $(\mathrm{P}<0.05)$ increase in $17 \beta$-HSD activity and significant $(\mathrm{P}<0.05)$ decrease in 17 -KSR comparison with the control group, and these effects were more pronounced in the combination group than each one. The increase in testicular 17 $\beta$-hydroxysteroid dehydrogenase (17- $\beta$ HSD) and decrease in 17-ketostroid reductase (17-KSR) may lead to the decrease of testosterone. One of the indicators of the chemical toxicity on reproductive system is the decreased level testosterone [37]. The decline in the activity of 17-KSR in animals treated with IONPs and AgNPs indicates their adverse effect on the production of testosterone hormone which in turn effects on the process of fertility via decreasing 
testosterone hormone production and sperm production and proliferation and hence motility, count and abnormality. On the other hand, the activity of $17 \beta$-HSD that convert testosterone to androstenedione, significantly increased in rats treated with AuNPs compared to control group.
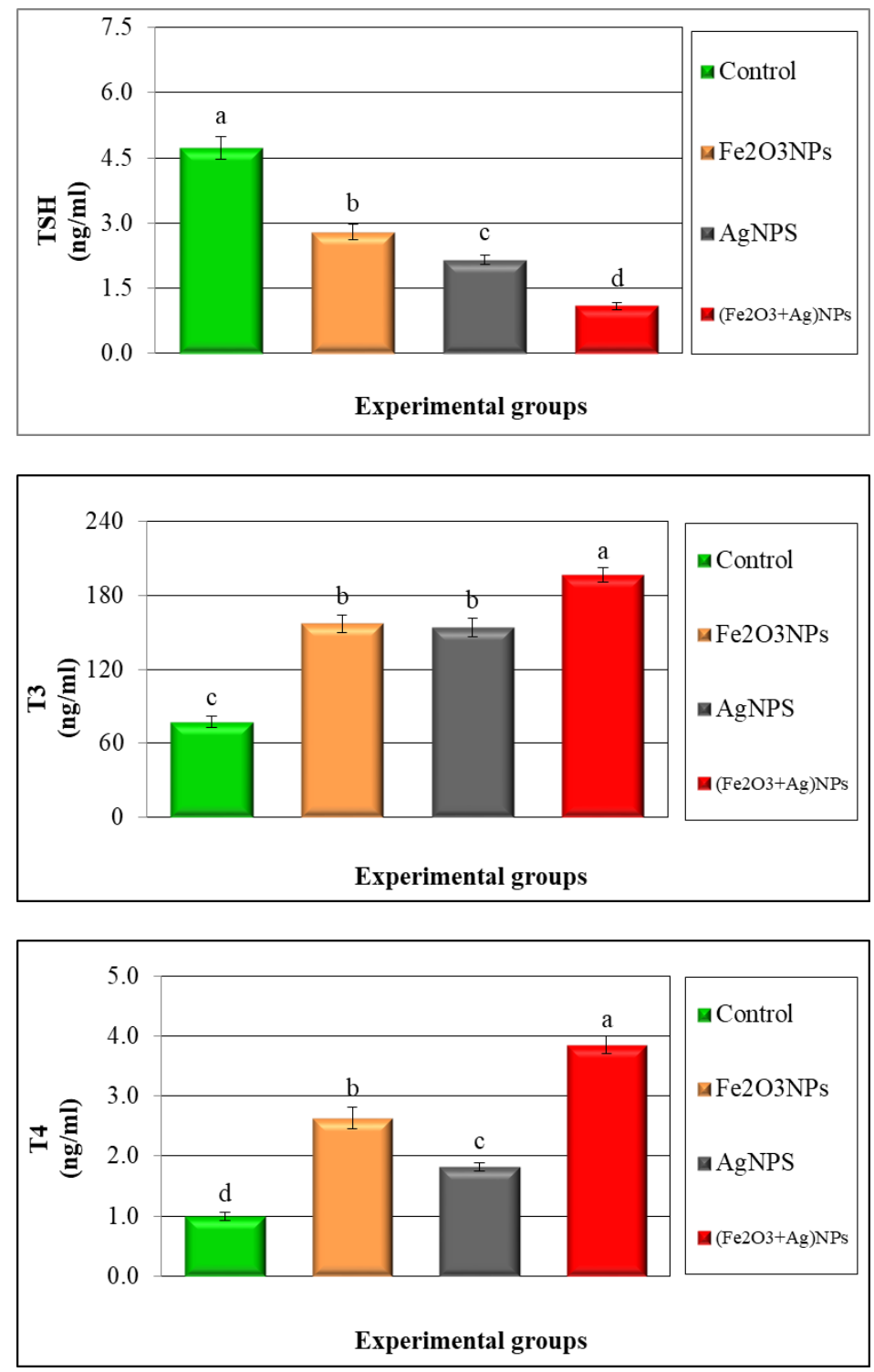

Figure 3 Mean values \pm SE of thyroid-Stimulating hormone, tri-Iodothyronine and thyroxin of male rats treated with iron oxide nanoparticles ( $\mathrm{Fe}_{2} \mathrm{O}_{3} \mathrm{NPs}$ ), silver nanoparticles (AgNPs) and their combination.

Table 3 Mean values \pm SE of the specific activities of testicular $17 \beta$-hydroxysteroid dehydrogenase and 17 -ketosteroid reductase of rats treated with iron oxide nanoparticles (Fe203NPs), silver nanoparticles (AgNPs) and their combination.

\begin{tabular}{|l|l|l|l|l|}
\hline \multirow{2}{*}{ Parameter } & \multicolumn{4}{l|}{ Experimental groups } \\
\cline { 2 - 5 } & Control & Fe203NPs & AgNPs & Fe203NPs+AgNPs \\
\hline $17 \beta-\mathrm{HSD}(\mathrm{U} / \mathrm{min} / \mathrm{mg})$ & $0.8 \pm 0.05 \mathrm{c}$ & $1.8 \pm 0.08 \mathrm{~b}$ & $1.9 \pm 0.08 \mathrm{~b}$ & $2.9 \pm 0.12 \mathrm{a}$ \\
\hline $\begin{array}{l}17-\mathrm{KSR} \\
(\mathrm{U} / \mathrm{min} / \mathrm{mg})\end{array}$ & $2.4 \pm 0.17 \mathrm{a}$ & $1.7 \pm 0.13 \mathrm{~b}$ & $1.8 \pm 0.05 \mathrm{~b}$ & $1.1 \pm 0.08 \mathrm{c}$ \\
\hline
\end{tabular}

Mean values within a row not sharing a common superscript letters $(a, b, c, d)$ weresignificantly different, $p<0.05$. $17 \beta-\mathrm{HSD}=$ Hydroxysteroid dehydrogenase, $17-\mathrm{KSR}=$ Ketosteroidreductase. 

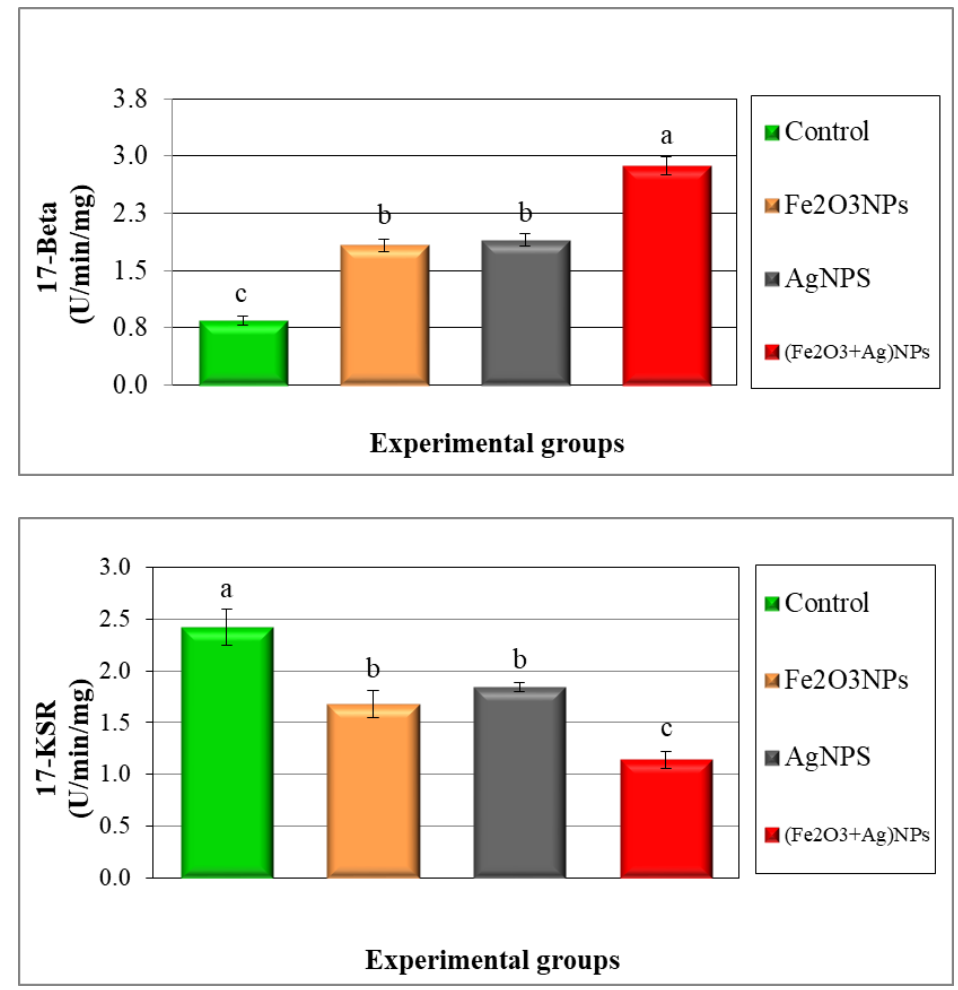

Figure 4 Mean values \pm SE of testicular $17 \beta$-hydroxysteroid dehydrogenase and17-ketosteroid reductase of male rats treated with iron oxide nanoparticles $\left(\mathrm{Fe}_{2} \mathrm{O}_{3} \mathrm{NPs}\right.$ ), silver nanoparticles (AgNPs) and their combination.

\section{Conclusion}

It was concluded that rats exposed to $\mathrm{Fe}_{2} \mathrm{O}_{3} \mathrm{NPs}$, AgNPs or their combination caused testes inflammation and sex hormones imbalance, which may affect reproductive performance. The result of this study provided insight into the importance between reproductive performance and toxicity of nanoparticles, which are widely incorporated in cosmetics, textiles, and various biomedical applications. Investigations should be considered carefully due to their impact upon society in many ways, such as potential risk to human health.

\section{Compliance with ethical standards}

\section{Acknowledgments}

The authors would like to thank the Dean of Institute of Graduate Studies and Research; and all administrative and teaching staffs at the institute for providing all the facilities required for this study.

\section{Disclosure of conflict of interest}

The authors declare that they have no competing interests.

\section{Statement of ethical approval}

The ethical committee at the Institute of Graduate Studies and Research, Alexandria University, Egypt approved this work.

\section{References}

[1] Ema M, Kobayashi N, Naya M, Hanai S andNakanishi J. (2010). Reproductive and developmental toxicity studies of manufacturednanomaterials. Reprod. Toxicol, 30, 343-352.

[2] Medina C, Santos-Martinez MJ, Radomski A, Corrigan OI and Radomski MW. (2007). Nanoparticles: pharmacological and toxicological significance. Br J. Pharmacol, 150, 552-558. 
[3] Kulthong K, Srisung S, Boonpavanitchakul K, Kangwansupamonkon W and Maniratanachote R. (2010). Determination of silver nanoparticle release from antibacterial fabrics into artificial sweat. Part Fiber Toxicol, 7, $2-9$.

[4] Chen X and Schluesener HJ. (2008). Nanosilver: a nanoproduct in medical application. Toxicol. Let, 176, 1-12.

[5] Ji JH, Jung JH, Kim SS, Yoon JU, Park JD, Choi BS, Chung YH, Kwon IH, Jeong J, Han BS, Shin JH, Sung JH, Song KS and Yu IJ. (2007). Twenty-eight-day inhalation toxicity study of silver nanoparticles in Sprague-Dawley rats. Inhal. Toxicol, 19, 857-871.

[6] Luoma PV. (2008). Cytochrome P450 and gene activation-from pharmacology to cholesterol elimination and regression of atherosclerosis. European. J. Clin. Pharmacol, 64, 841-850.

[7] Braydich-Stolle L, Hussain S, Schlager JJ and Hofmann MC. (2005). In vitro Cytotoxicity of Nanoparticles in Mammalian Germline Stem Cells. Toxicol. Sci, 88, 412-419.

[8] Hussain SM, Hess KL, Gearhart JM, Geiss KT and Schlager JJ. (2005). In vitro Toxicity of Nano particles in BRL 3A Rat Liver Cells. Toxicol. In Vitro, 19, 975-983.

[9] Arora S, Jain J, Rajwade JM and Paknikar KM. (2008). Cellular Responses Induced by Silver Nanoparticles: In Vitro Studies. Toxicol. Let, 179, 93-100.

[10] Krause W. (1995). Computer-assisted semen analysis systems: comparison with routine evaluation and prognostic value in male fertility and assisted reproduction. Human Reprod, 10, 60-66.

[11] Dunson DB, Winberg CR, Perreault SD and Chapin RE. (1999).Summarizing the motion of self-propelled cells: applications to sperm motility, Biometrics, 55, 537-543.

[12] Wells ME and Awa OA. (1970). New technique for assessing acrosomalcharacteristics of spermatozoa. J. Dairy Sci, 53, 227-232.

[13] Zirkin BR and Chen H. (2000). Regulation of Leydig cell steroidogenic function during aging. Biol. Reprod, 63, 977-981.

[14] Sakuma Y. (2009). Gonadal steroid action and brain sex differentiation in the rat. J. Neuroendocrinol, 21, 410414.

[15] Kjeld JM, Kuku SF, Harsoulis P, Fraser TR, Puah CM and Joplin GF. (1976). Infusions of hFSH and hLH in normal men. II. Serum testosterone response to infusedhLH and hFSH.,ActaEndocrinol, 81, 234-242.

[16] Closset, J., Hennen, G., 1988. Biopotency of highly purified FSH and LH on the testis of immature hypophysectomized rats. J. Endocrinol., 119: 1-542.

[17] Teerds KJJ, Rommerts RFG, De Rooij DG, Stocco DM, Colenbrander B, Gwensing J and Hennen G. (1989). Effects of pure FSH and LH preparations on the number and function of Leydig cells in immature hypophysectomized rats. J. Endocrinol, 120, 97-106.

[18] Katryna B and Anita PP. (1980). Purification of rat testicular microsomal 17-ketosteroid reductase. Evidence that 17-ketosteroid reductase and 17-bhydroxysteroid dehydrogenase are distinct enzymes. J. Biol. Chem, 255, 55525559.

[19] Bogovich K and Payne AH. (1980). Purification of rat testicular microsomal 17 $\beta$ - hydroxysteroid dehydrogenase are distinct enzymes. J. Biol. Chem, 255, 5552-5559.

[20] Hedayati M, Yazdanparast R and Azizi F. (2001). Determination of human tumor necrosis factor $\alpha$ by a highly sensitive enzyme immunoassay. Biochem. Biophys. Res. Comm, 289, 295-298.

[21] Hupp TR, Lane DP and Ball KL. (2000). Strategies for manipulating the p53 pathway in the treatment of human cancer. Biochem. J, 352, 1-17.

[22] Renard P, Ernest I, Houbion A, Art M, Le Calvez H, Raes M and Remacle J. (2001). Development of a sensitive multi-well colorimetric assay for active NF kappa B. Nucleic Acids Res, 29, 1-21.

[23] Gottifredi V and Prives C. (2001). Getting p53 out of the nucleus. Science, 292, 1851-1852.

[24] Yang A, Kaghad M, Caput D and McKeon F. (2002). On the shoulders of giants: p63, p73 and the rise of p53. Trends Genet, 18, 90-95.

[25] Yoshida H, Kuwauchi Y, Jinschek JR, Sun K, Kohyama M, Shimada S, Haruta M and Takeda S. (2012). Gas Molecules Interacting with Supported Nanoparticulate Catalysts at Reaction Conditions. Sci. Magazine, 335, 317-319. 
[26] Hughes GA. (2005). Nano structure-Mediated drug delivery, Nanomedicine, 1, 22-30.

[27] Manin OI, Nikolaev VA, Kolomiitsev AA and LebedenkoIIu. (2007). Comparative toxicological evaluation of domestic golden alloys for soldering. Stomatologiia (Mosk), 86, 64-67.

[28] Carlson C, Hussain SM and Schr AM. (20080. Unique cellular interaction of nanoparticles: size dependent generation of reactive oxygen species. J. Phys. Chem. B, 112, 13608-13619.

[29] Yoshida Y, Itoh N, Saito Y, Hayakawa M and Niki E. (2004). Application of water-soluble radical initiator, 2, 2'azobis-[2-(2-imidazolin-2-yl) propane] dihydrochloride, to a study of oxidative stress. Free Radical res, 38, 375384.

[30] De-Lamirande E and Gagnon C. (1992). Reactive oxygen species and human spermatozoa. J. andrology, 13, 379386.

[31] Aziz N, Saleh RA, Sharma RK, Lewis-Jones I, Esfandiari N, Thomas AJ and Agarwal A. (2004). Novel association between sperm reactive oxygen species production, sperm morphological defects, and the sperm deformity index. Fertil. Steril, 81, 349-354.

[32] Nasri S, Rezai-Zarchi S, Kerishchi P and Sadeghi S. (2015). The Effect of Iron Oxide Nanoparticles on Sperm Numbers and Mobility in Male Mice. Zahedan J. Res. Med. Sci, 17, 29-31.

[33] Stocco DM. (2000). The role of the StAR protein in steroidogenesis: challenges for the future. J. Endocrinol, 164, 247-253.

[34] Buzzard JJ, Morrison JR, O'Bryan MK, Song Q and Wreford NG. (2000). Developmental expression of thyroid hormone receptorsin the rat testis. Biol. Reprod, 62, 664-669.

[35] Chandra AK, Sengupta P, Goswami H and Sarkar M. (2013). Effects of dietary magnesium on testicular histol- ogy, steroidogenesis, spermatogenesis and oxidative stress markers in adult rats. Indian J. Exp. Biol, 51, 37-47.

[36] Mendis-Handagama SM and Ariyaratne HB. (2001). Differentiation of the adult Leydig cell population in the postnatal testis. Biol. Reprod, 65, 660-671.

[37] Yoshida M, Kitani T, Takenaka A, Kudoh K, Katsuda SI and Taya K. (2002). Lack of effects of oxolinic acid on spermatogenesis in young male adult and aged Wistar rats. Food. Chem. Toxicol, 40, 1815-1825. 